\title{
Tissue Engineering: Key Elements and Some Trends
}

Received on July 1, 2004; DOI: 10.1002/mabi.200400094

\section{Introduction}

It is the believe of many that tissue engineering (or as some scientists prefer - regenerative medicine) is and will increasingly be the focus of biomaterials research, justified by a very significant and well-known clinical need for the establishment of alternative therapies for the treatment of tissue loss or end-stage organ failure, as the transplantation of tissues or organs in these patients is often limited by donor scarcity and is highly associated to the risk of rejection and disease transfer. In this sense, tissue engineering will lead to a great impact on health care providing in the coming decades.

This expected evolution would also create the need for the education of new scientists that are "hybrid" and can perform multidisciplinary research, combining materials and biotechnology. Nevertheless, even the basics of tissue engineering are not clear for many researchers working on the general field of biomaterials and biomedical engineering. Conventional biomaterials have been very useful in the past, and have improved the life quality of many patients. Good examples are many different prosthesis, such as for instances the knee and hip joints. However it is easy to recognize that there are still no materials available that can adequately replace several functional tissues, such as bones, cartilage, or large bone segments, not to speak on complex organs. Just as an example, in the world market for bone grafts the so-called synthetic biomaterials represent only $10 \%$, while autografts still account for around $50 \%$. Therefore, despite the enormous benefits the contemporary technology has brought, the outer limits have been reached and new breakthroughs can only be expected from a novel hybrid technology that will reduce the shortcomings of the current material technology. Such a combined, biology driven approach is referred to as "tissue engineering", by which biological tissues are engineered through combining material technology and biotechnology.

Tissue engineering typically involves the culture of living human cells usually in polymeric (ceramic) scaffold materials, ex vivo, and subsequently allowing them to develop into a three dimensional tissue.

Substantial gains are expected to be obtained both from a medical and economic standpoint as a result of this emerging technology. It is expected that, in the near future, tissue engineering can take advantage of the recent breakthroughs in the fields of stem cell research, genomics and materials technology.

Tissue engineering involves several steps, that go from (i) the selection, isolation, and culturing of primary (progenitor or stem from different origins) cells, inducing their differentiation to specific phenotypes, (ii) to the way they are cultured (not pre-cultured and just seeded and immediately implanted, or cultured in static conditions or in an all range of different specifically designed bio-reactors), (iii) to the design of adequate scaffolds, including the selection of adequate materials and routes to process them, the respective porosity, interconnectivity, surface characteristics, hydrophilicity, etc., and (iv) to the use of adequate animal models that will allow to test the efficacy of different tissue engineering approaches and the potential of different constructs (distinct combinations of scaffolds/cells/in vitro culturing conditions). Finally, all the related ethical considerations, especially when considering the use of stem cells (and potentially embryonic stem cells) and animal studies, as well as the need for proper standards must be taken into account, and unfortunately tend to differ from country to country.

This introductory essay will very briefly present the stateof-the-art on topics such as: cells for tissue engineering (stem cells, isolation, characterization, etc.), culturing conditions (static, media, bioreactors, etc.), scaffolds (design, processing, choice of materials, etc.) and needed animal models to test the developed tissue engineering strategies and respective constructs.

The Special Topic on Tissue Engineering, that Macromolecular Bioscience invited me to organize as a Guest Editor, comprises a selection of papers that touch several relevant and emerging topics on tissue engineering, providing the reader with a feeling on what is the present status of the field.

\section{Scaffolds for Tissue Engineering}

Tissue engineering offers the possibility to help in the regeneration of tissues damaged by disease or trauma and in some cases to create new tissues and replace failing or malfunctioning organs. ${ }^{[1-7]}$ This is typically done through the use of degradable biomaterials to either induce 
surrounding tissue and cell ingrowth or to serve as temporary scaffolds for transplanted cells to attach, grow, and maintain differentiated functions. ${ }^{[3-5,7-17]}$ In any case, the role of the biomaterial is temporary, but rather crucial to the success of the strategy. Therefore, the selection of a scaffold material is both a critical and difficult choice.
There are many biocompatible materials available among metals, ceramics and polymers, but the criteria of biodegradability and non-brittle nature (ideally with tissue matching mechanical properties) excludes the use of all metals and most ceramics as scaffolds materials ${ }^{[3,18]}$ and gives preference to biodegradable polymers for most of the
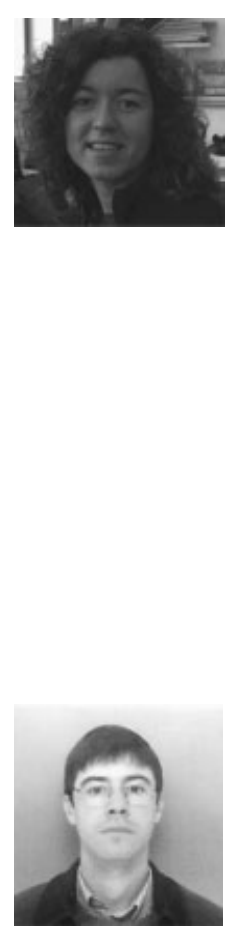

Manuela E. Gomes was born in Águeda (Portugal) in 1973. She graduated in Metallurgical and Materials Engineering at the Faculty of Engineering of the University of Porto in July 1997. In the last year of graduation, she started her research work on Biomaterials, which she continued after graduation in a training period at Isotis, Bilthoven, The Netherlands, (locally supervised by Prof. Clemens van Blitterswijk and Dr. Joost de Bruijn). In 2001 she obtained her Master degree in Polymer Engineering at the University of Minho. Her MSc. thesis was focused on the development and characterization of tissue engineering scaffolds based on starch polymers. She has been a researcher of the 3B's Research Group (Biomaterials, Biodegradables, Biomimetics) since this Group was created in the University of Minho, working under the supervision of Prof. Rui L. Reis. She has also worked in the Department of Bioengineering at the University of Rice (Houston, TX, USA) under the supervision of Prof. Antonious G. Mikos. The main topic of her research is the development of bone tissue engineering approaches using natural origin polymeric scaffolds seeded with marrow stromal (autologous) cells and cultured under flow perfusion conditions. Other research interests include the development of innovative methodologies for the production of multifunctional scaffolds for tissue engineering applications, design of improved culturing systems and in vitro and in vivo functionality evaluation of tissue engineered constructs. She is an author of 10 papers published in international refereed journals, 13 book chapters and 38 communications in conferences.

Rui L. Reis was born in 1967 in Porto, Portugal, where he still lives. At the present, he is an Associate Professor of Materials Science, Biomaterials and Tissue Engineering at the Department of Polymer Engineering of the University of Minho, in the Northern part of Portugal, where he is Director of the 3B's Research Group (Biomaterials, Biodegradables and Biomimetics), a Unit of Excellence partially funded by the Portuguese Government. He previously was a Lecturer at the Department of Metallurgical and Materials Science Engineering, University of Porto. Dr. Rui L. Reis is also the Director of R\&D of the Cork Industries Holding of the AMORIM Group, one of the main economical groups with world-wide operations based in Portugal, where he directs a team fully devoted to the development of new cork based products. Dr. Rui L. Reis education background includes: (i) a five years graduation in Metallurgical Engineering, University of Porto, (ii) a two years Master degree in Materials Science and Engineering Biomaterials - obtained in a joint program of the six major technical Universities in Portugal and (iii) a Ph.D. degree on Polymer Engineering - Biomaterials, University of Minho, Portugal, that was prepared in cooperation with Brunel University, UK. Rui L. Reis has been involved in biomaterials research since 1990. His main area of research is the development of biomaterials from starch and other natural origin polymers (casein, soy, chitin, chitosan, algae) that his group originally proposed for a range of biomedical applications, including bone replacement and fixation, drug delivery carriers, partially degradable bone cements and tissue engineering scaffolding. He has also been involved in several EU funded projects, and he is currently the coordinator of the only Network of Excellence (NoE) on Tissue Engineering under the FP6. As a result of these and other projects he is directing at the present moment the work of around 40 post-graduation researchers (Postdocs and Ph.D. students). Rui L. Reis is an author of more than 100 papers on scientific journals, 1 international patent, 3 books, 5 journal special issues, around 80 book chapters in books of international circulation and on international Encyclopaedias, and more than 360 communications in conferences. Around 330 of those communications were presented in international meetings, including around 40 plenary or invited talks. He presented also 35 invited lectures in other universities or research institutes. As a result of his academic activities Rui L. Reis has been awarded several prizes. The two last ones were: (i) the ESAFORM 2001 Scientific Prize for his work on processing of starch based biomaterials and (ii) the Jean LeRay Award 2002 by the European Society for Biomaterials for its outstanding contributions to the biomaterials field as a young scientist. He has organized several international meetings and workshops and is active in the Editorial Board of several scientific journals. 
applications within the tissue engineering and regenerative medicine field.

Consequently, the first aspect of the scaffold design to be considered is related to the selection of the biodegradable polymer that will be used for its design and production. Traditionally, in spite of the wide range of biodegradable polymers available, there is a strong tendency to choose those that have history of regulatory approval. This leads to the use of materials, which were primarily developed for other applications (the so-called "from-the shelf" materials), instead of letting the application guide the choice of the material. ${ }^{[19]}$ In fact poly(lactic acid) and poly(glycolic acid) are still the gold standard, ${ }^{[11,20-24]}$ although some other groups such as ourselves ${ }^{[25-34]}$ defend the use of other types of biodegradable polymers. This conservative behavior of the research community has created additional difficulties for the development of new materials with improved properties, specifically tailored for tissue engineering applications.

The definition of the most adequate scaffold design and the correspondent required properties, is mainly determined by the tissue engineering approach selected for the regeneration of a specific tissue, as the scaffold must be able to induce the desired tissue response. ${ }^{[35,36]}$ Although three-dimensional porous structures have been recognized as the most appropriate design to sustain cell adhesion and proliferation, several specific applications in tissue engineering may take advantage of other design formats or combination of different materials designs. ${ }^{[19]}$ In fact, as the demand for new and more sophisticated scaffolds develops, materials are being designed that have a more active role in guiding tissue development. Instead of merely holding cells in place, these matrices are designed to accomplish other functions through the combination of different format features and materials. ${ }^{[15]}$ A good example of this is the use of drug delivery devices that can act simultaneously as scaffolds for cells growth. Other approaches include, for example, the combination (or incorporation) of microspheres or nanospheres (with encapsulated cells, growth factors or other therapeutic agents) with a polymeric matrix. This type of multifunctional devices can also be designed to act as an injectable material, with the advantage of allowing minimal invasive surgery procedures for their implantation in the body.

Another important field of current research in tissue engineering scaffolding is related to the development of external-stimuli-responsive matrices, ${ }^{[37,38]}$ i.e., matrices that have in their composition and structure certain elements that allow them to respond to a particular specific stimuli that can be produced by different mechanisms, such as magnetic, electric, ultrasound, irradiation or other effects. Other scaffolds are designed to respond to several physiological stimuli like $\mathrm{pH}$, temperature or enzymatic concentrations changes, just to cite some examples. This can enhance the ability of tissue engineering constructs to resemble natural human tissues and therefore perform a better functioning in vivo, but also in vitro if provided with adequate culture conditions.

\section{Cells for Tissue Engineering}

A further important consideration for the most widely studied tissue engineering approaches, which are based on the seeding and extended in vitro culturing of cells within the scaffold prior to implantation, is the cell source and the ability to control cell proliferation and differentiation. Primary cells derived from the patient's own healthy tissues (i.e., autogenic cells) could be the first obvious choice, since this avoids many of the problems associated with immune rejection of foreign tissues. ${ }^{[36,39]}$ However these cells are not, in most cases, readily available in sufficient quantities for immediate use. By in vitro culture their number may be increased, but to reach a cell population necessary for a specific application may take from days to weeks, ${ }^{[36,39]}$ mainly depending on cell type. Primary cells derived from normal donors of the same (i.e., allogeneic cells) or different species (i.e., xenogeneic cells) are, at least in concept, readily available in sufficient quantities due to the number of potential donors and to cryopreservation possibilities. However, in this case, rejection by the host's immune system and the possibility of diseases transmission, are serious risks to be considered, ${ }^{[36,39]}$ The use of cell lines can overcome some of these limitations, but these immortalized cells exhibit some of the properties of neoplastically transformed cells. Therefore, cells lines can be considered to be partially transformed cells with a predisposition to become fully neoplastic cells capable of forming tumors in the recipient. ${ }^{[36]}$

The recent identification of human embryonic stem cells $^{[40,41]}$ - cells that can give rise to essentially all cell types in the body, depending on the culturing conditions - offers probably the most exciting alternative source of cells for tissue engineering. However, researchers are still far from being able to control the differentiation of embryonic stem cells in culture. In addition, the research on embryonic cells brings up a range ethical and legislative problems ${ }^{[40,41]}$ that differ from country to country. A more immediate goal would be to isolate the so-called progenitor cells from tissues. These are stem cells that have already partly differentiated so as to change the course of their development. However, because they are not yet fully differentiated, they stay flexible enough to give origin to several different cell types. ${ }^{[40,41]}$ For example, from the human bone marrow or from adipose tissue it is possible to isolate progenitor cells that can be differentiated in the laboratory to form osteoblasts that make bone. ${ }^{[42]}$ These recent developments in the stem cell field have impacted significantly on the progress of tissue engineering, ${ }^{[42]}$ and have opened a novel avenue for obtaining an unlimited supply of cells. 


\section{Cell Culturing in Tissue Engineering: Static Conditions and Bioreactors}

Besides the selection of the scaffold material and the cell source (the two main components of tissue engineering approaches based on in vitro culturing of cells-scaffold constructs), it is necessary to develop more advanced procedures for growing cells in large quantities, ${ }^{[43,44]}$ optimizing the in vitro culturing systems currently used. The most widely used culturing technique in tissue engineering studies is static culturing, which is often characterized by non-homogenous cell distribution, confining the majority of the cells to the outer surfaces of the scaffold, which in turn results to an inhomogeneous distribution of the in vitro generated extracellular matrix. ${ }^{[45-47]}$ In order to overcome this limitation, several culturing systems which consist basically on using growth chambers equipped with stirrers and sensors that regulate the appropriate amounts of nutrients, gases and waste products have been developed. ${ }^{[45-47]}$ These systems, so-called bioreactors, may have different designs, attempting to achieve one or more of the following objectives: i) maintain an uniform distribution of cells into the 3D scaffolds, ii) provide adequate levels of oxygen, nutrients, cytokines and growth factors iii) expose the cultured cells to mechanical stimuli. Furthermore, experiments involving in vitro bioreactor culturing can also be designed to study the effects of specific biochemical and physical signal involved in cell/tissue development and function, providing useful information on the processes that lead to the formation of 3-D tissues starting from cells/ scaffolds tissue engineered constructs. ${ }^{[5]}$ Bioreactors are also one of the focus of the development of a manufacturing technology for tissue engineered products that can be used "in the real industrial world", because they represent a chemically and mechanically controlled environment in which a tissue-like construct can be grown in reproducible conditions. ${ }^{[43]}$

\section{In Vivo Functionality: Animal Models}

Following in vitro studies and prior to clinical trials it is current and logical to perform in vivo studies in different animal models. ${ }^{[48-50]}$ Several parameters are in the centre of such evaluation. Inflammatory response for example, is crucial and has to be evaluated for any type of biomaterial since an unresolved inflammatory process will ultimately will lead to rejection. It is however, of major importance to reduce as much as possible the number of animals involved in the in vivo evaluation of potential biomaterials and/or tissue engineering scaffolds and constructs.

In our group we believe in an approach that tries to study exhaustively the developed constructs in vitro minimizing the number of animal testing. This is also the approach of the European Union (EU) Network of Excellence on Tissue Engineering of Bone and Cartilage that we coordinate
(EXPERTISSUES) and involves 20 partners from 13 countries. ${ }^{[51]}$ However before any clinical application of tissue engineering constructs (so called combination products) animal experimentation is always required. For achieving this goal it is crucial to establish strict and standardized protocols of implantation as well as adequate animal models. ${ }^{[48,50]}$ The models have to be optimized in order to provide information in different areas avoiding then the use of excessive animals. The use of implantation procedures that can be compared with others used in different groups is of main importance.

The first step of animal implantation studies that is relevant for tissue engineering involves the implantation of the developed scaffolds, on its own (without cells) or after being seeded with cells, in a subcutaneous model (many times nude mice in order to be able to use human cells). ${ }^{[2,53]}$ The subcutaneously implantation of the scaffolds is aimed in the non-cell seeded materials to determine the effect of a specific material degradation and resorption by products in triggering the immune system and non-specific inflammatory reactions. The implanted species are typically harvested after different times and histological analysis is performed. Classical immunohistochemistry techniques are then used to identify the type of cells at the interface material-tissue and complemented with gene expression analysis in situ (ELISA and RT-PCR) for quantification of inflammatory chemical mediators also know to have a major role in resorption processes. It is also possible to use the in vivo experiments to apply in situ methods of pathology to study the tissue reaction to implanted materials. The same model can be used with scaffolds seeded with cells to look for instances for the osteogenic potential of the constructs in a non bony site local. ${ }^{[33,48]}$

Another type of approach aims to understand biomaterial-related functionality facilitating advances in the construction of improved and novel scaffolds for tissue engineering. Again subcutaneous implantation can be performed. Properties such as porosity, pore size and interconnectivity of the produced scaffolds are then evaluated in terms of suitability to encourage tissue growth and vascularization. ${ }^{[54-56]}$ Furthermore, it is important the degradation rate to be coupled to the rate of tissue formation, which can also be evaluated in this type of experiments.

More relevant experiments have to be performed in larger animals, typically using critical size (calvarial, femoral, etc.) defects. ${ }^{[57]}$ Typically studies that start from rats and mice proceed to rabbits and goats or pigs, although some groups also use dog models. The size of the animal is especially relevant to assess the effect of load on loadbearing implantation sites. In such type of experiments the developed systems (scaffolds plus cells) are implanted, including empty defects and scaffolds without cells as controls. At appropriate time points animals are sacrificed and tissue formation is analyzed by different methodologies, 
namely using micro-CT, immunohistochemistry, and quantitative methodologies.

[1] C. M. Agrawal, K. A. Athanasiou, J. D. Heckman, Mater. Sci. Forum 1997, 250, 115.

[2] J. H. Braybrook, L. D. Hall, Prog. Polym. Sci. 1990, 15, 715.

[3] V. Maquet, R. Jerome, Porous Mater. Tissue Eng. 1997, 250, 15.

[4] D. J. Mooney, P. M. Kaufmann, K. Sano, K. M. McNamara, J. P. Vacanti, R. Langer, Transplant $P$ 1994, 26, 3425.

[5] B. Saad, S. Matter, G. Ciardelli, G. K. Uhlschmid, M. Welti, P. Neuenschwander, U. W. Suter, J. Biomed. Mater. Res. 1996, 32, 355 .

[6] M. Sittinger, J. Bujia, W. W. Minuth, C. Hammer, G. R. Burmester, Biomaterials 1994, 15, 451.

[7] R. C. Thomson, M. J. Yaszemski, J. M. Powers, A. G. Mikos, J. Biomater. Sci. Polym. Ed. 1995, 7, 23.

[8] M. G. Dunn, P. N. Avasarala, J. P. Zawadsky, J. Biomed. Mater. Res. 1993, 27, 1545.

[9] W. W. Minuth, M. Sittinger, S. Kloth, Cell Tissue Res. 1998, $291,1$.

[10] A. G. Mikos, G. Sarakinos, S. M. Leite, J. P. Vacanti, R. Langer, Biomaterials 1993, 14, 323.

[11] L. E. Freed, G. Vunjak-Novakovic, R. J. Biron, D. B. Eagles, D. C. Lesnoy, S. K. Barlow, R. Langer, Biotechnology (N Y) 1994, 12, 689 .

[12] C. T. Laurencin, M. A. Attawia, H. E. Elgendy, K. M. Herbert, Bone 1996, 19, S93-S99.

[13] S. L. Ishaug, G. M. Crane, M. J. Miller, A. W. Yasko, M. J. Yaszemski, A. G. Mikos, J. Biomed. Mater. Res. 1997, 36, 17.

[14] C. H. Rivard, C. J. Chaput, E. A. Desrosiers, L. H. Yahia, A. Selmani, J. Appl. Biomater. 1995, 6, 65.

[15] A. Mikos, A. Thorsen, L. Czerwonka, Y. Bao, R. Langer, Polymer 1994, 35, 1068

[16] T. Tateishi, G. Chen, T. Ushida, T. Murata, S. Mizuno, in: Tissue Engineering and Biodegradable EquivalentsScientific and Clinical Applications, K.-U. Lewandrowski, D. Wise, D. Trantolo, J. Gresser, M. Yaszemski, D. Altobelli, Eds., Marcel Dekker Inc., New York 2002.

[17] J. Elisseeff, R. Langer, Y. Yamada, in: Tissue Engineering and Biodegradable Equivalents-Scientific and Clinical Applications, K.-U. Lewandrowski, D. Wise, D. Trantolo, J. Gresser, M. Yaszemski, D. Altobelli, Eds., Marcel Dekker Inc., New York 2002, p. 99.

[18] R. Thompson, M. C. Wake, M. Yaszemski, A. G. Mikos, $A d v$. Polym. Sci. 1995, 122, 247.

[19] J. Pachence, J. Kohn, in: Principles of Tissue Engineering, R. Lanza, R. Langer, W. Chick, Eds., Academic Press, New York 1997, p. 273.

[20] D. W. Hutmacher, J. C. Goh, S. H. Teoh, Ann. Acad. Med. Singapore 2001, 30, 183.

[21] K. A. Athanasiou, C. M. Agrawal, F. A. Barber, S. S. Burkhart, Arthroscopy 1998, 14, 726.

[22] H. R. Lin, C. J. Kuo, C. Y. Yang, S. Y. Shaw, Y. J. Wu, J. Biomed. Mater Res. 2002, 63, 271.

[23] C. M. Agrawal, R. B. Ray, J. Biomed. Mat. Res. 2001, 55, 141

[24] L. Lu, A. G. Mikos, MRS Bull 1996, 21, 28.

[25] M. Gomes, J. Godinho, D. Tchalamov, A. Cunha, R. Reis, J. Appl. Med. Polym. 2002, 6, 75.
[26] M. Gomes, J. Godinho, D. Tchalamov, A. Cunha, R. Reis, Mat. Sci. Eng. C 2002, 20, 19.

[27] M. Gomes, A. Salgado, R. Reis, in: Polymer Based Systems on Tissue Engineering, Replacement and Regeneration, R. Reis, D. Cohn, Eds., Kluwer Academic Publishers, Amsterdam 2002, pp. 221-249.

[28] M. E. Gomes, E. Behravesh, V. Sikavitsas, R. L. Reis, A. G. Mikos, J. Biomed. Mater. Res. 2003, 67A, 87.

[29] M. E. Gomes, A. S. Ribeiro, P. B. Malafaya, R. L. Reis, A. M. Cunha, Department of Polymer Engineering, U. o. M. B. P. m. d. u. p. Biomaterials 2001, 22, 883.

[30] P. Malafaya, R. Reis, Key Eng. Mat. 2003, 240-242, 39.

[31] P. B. Malafaya, C. Elvira, A. Gallardo, J. San Româan, R. L. Reis, J. Biomater. Sci. Polym. Ed. 2001, 12.

[32] P. B. Malafaya, M. E. Gomes, A. J. Salgado, R. L. Reis, Adv. Exp. Med. Biol. 2003, 534, 201.

[33] S. C. Mendes, J. Bezemer, M. B. Claase, D. W. Grijpma, G. Bellia, F. Degli-Innocenti, R. L. Reis, K. de Groot, C. A. van Blitterswijk, J. D. de Bruijn, Tissue Eng. 2003, 9 Suppl 1, S91-101.

[34] A. Salgado, M. E. Gomes, O. Coutinho, R. L. Reis, D. W. Hutmacher, Mater. Sci. Eng., C 2002, 20, 27-33.

[35] M. E. Gomes, R. L. Reis, Inter. Mater. Rev. 2004.

[36] J. Hardin-Young, J. Teumer, R. Ross, N. Parenteau, in: Principles of Tissue Engineering, 2nd edition, R. Lanza, R. Langer, J. Vacanti, Eds., Academic Press, New York 2000, p. 281.

[37] J. Kost, R. Langer, Adv. Drug Delivery Rev. 2001, 46, 125.

[38] P. Malafaya, G. Silva, E. Baran, R. Reis, Curr. Opin. Solid State Mat. Sci. 2002, 6, 283.

[39] R. Nerem, in: Principles of Tissue Engineering, 2nd edition, R. Lanza, R. Langer, J. Vacanti, Eds., Academic Press, New York 2000, pp. 9-15.

[40] R. S. Langer, J. P. Vacanti, Sci. Am. 1999, 280, 86.

[41] R. Pedersen, Sci. Am. 1999, $280,44$.

[42] A. I. Caplan, S. Bruder, in: Principles of Tissue Engineering, R. Lanza, R. Langer, W. Chick, Eds., Academic Press 1997, p. 603.

[43] J. P. Vacanti, C. A. Vacanti, in: Principles of Tissue Engineering, W. Chick, Ed., Academic Press, New York 1997, p. 1.

[44] L. C. Lu, A. G. Mikos, Mrs Bulletin 1996, 21, 28.

[45] V. I. Sikavitsas, G. N. Bancroft, A. G. Mikos, J. Biomed. Mater. Res. 2002, 62, 136.

[46] E. A. Botchwey, S. R. Pollack, E. M. Levine, C. T. Laurencin, J. Biomed: Mater. Res: 2001, 55, 242.

[47] A. S. Goldstein, T. M. Juarez, C. D. Helmke, M. C. Gustin, A. G. Mikos, Department of Bioengineering, I. o. B.; Bioengineering, R. U. H. T. X. U. S. A.; Rice U, H. T. X. Biomaterials 2001, 22, 1279.

[48] M. C. Kruyt, S. M. van Gaalen, F. C. Oner, A. J. Verbout, J. D. de Bruijn, W. J. Dhert, Biomaterials 2004, 25, 1463.

[49] C. J. Kirkpatrick, Med. Device Technol. 1998, 9, 22.

[50] M. Spector, P. Lalor, in: Biomaterials Science: an Introduction to Materials in Medicine, B. Ratner, A. Hoffman, F. Schoen, J. Lemons, Eds., Academic Press, New York 1996.

[51] EXPERTISSUES - Novel therapeutic strategies for tissue engineering of bone and cartilage using second generation biomimetic scaffolds (Project $n r$. 500283-2), Network of Excellence - EU $6^{\text {th }}$ Framework Programme, coordinated by Rui L. Reis (University of Minho), Portugal, 2004-2009.

[52] P. H. Krebsbach, S. A. Kuznetsov, K. Satomura, R. V. Emmons, D. W. Rowe, P. G. Robey, Transplantation 1997, $63,1059$. 
[53] J. A. Allay, J. E. Dennis, S. E. Haynesworth, M. K. Majumdar, D. W. Clapp, L. D. Shultz, A. I. Caplan, S. L. Gerson, Hum. Gene Ther. 1997, 8, 1417.

[54] C. K. Colton, Cell Transplant 1995, 4, 415.

[55] C. Hidaka, C. Ibarra, J. A. Hannafin, P. A. Torzilli, M. Quitoriano, M. S. S. Jen, R. F. Warren, R. G. Crystal, Tissue Eng. 2002, 8, 93.

[56] W. L. Murphy, C. A. Simmons, D. Kaigler, D. J. Mooney, J. Dent. Res. 2004, 83, 204.

[57] P. Buma, W. Schreurs, N. Verdonschot, Biomaterials 2004, $25,1487$.
Manuela E. Gomes, Rui L. Reis 3Bs Research Group - Biomaterials, Biodegradables and Biomimetics, University of Minho, Campus de Gualtar, 4710-057 Braga, Portugal Department of Polymer Engineering, University of Minho, Campus de Azurém, 4800-058 Guimarães, Portugal megomes@dep.uminho.pt; rgreis@dep.uminho.pt www.dep.uminho.pt/3bs 